\title{
GEO-QUESTIONNAIRE: A SPATIALLY EXPLICIT METHOD FOR ELICITING PUBLIC PREFERENCES, BEHAVIOURAL PATTERNS, AND LOCAL KNOWLEDGE - AN OVERVIEW
}

\author{
Michą Czepkiewicz ${ }^{1}$, Piotr Jankowski ${ }^{2,3}$, Zigigniew Zwoliński ${ }^{3}$ \\ ${ }^{1}$ Faculty of Civil and Environmental Engineering, University of Iceland, Reykjavik, Iceland \\ ${ }^{2}$ Department of Geography, San Diego State University, San Diego, USA \\ ${ }^{3}$ Institute of Geoecology and Geoinformation, Adam Mickiewicz University in Poznań, Poland
}

Manuscript received: December 12, 2017

Revised version: August 20, 2018

\begin{abstract}
CZePKIEwicz M., Jankowski P., Zwoliśski Zв., 2018. Geo-questionnaire: a spatially explicit method for eliciting public preferences, behavioural patterns, and local knowledge - an overview. Quaestiones Geographicae 37(3), Bogucki Wydawnictwo Naukowe, Poznań, pp. 177-190, 4 figs, 1 table.

ABSTRACT: Geo-questionnaires have been used in a variety of domains to collect public preferences, behavioural patterns, and spatially-explicit local knowledge, for academic research and environmental and urban planning. This paper provides an overview of the method focusing on the methodical characteristics of geo-questionnaires including software functions, types of collected data, and techniques of data analysis. The paper also discusses broader methodical issues related to the practice of deploying geo-questionnaires such as respondent selection and recruitment, representativeness, and data quality. The discussion of methodical issues is followed by an overview of the recent examples of geo-questionnaire applications in Poland, and the discussion of socio-technical aspects of geo-questionnaire use in spatial planning.
\end{abstract}

KEY wORDS: public participation GIS, Geoweb methods, spatial planning, online survey, local knowledge

Corresponding author: Zbigniew Zwoliński, ZbZw@amu.edu.pl

\section{Introduction}

Geo-questionnaire is a scalable method for soliciting and collecting public input by way of answering a set of prepared questions on topics that have explicit and/or implicit spatial connotations (Jankowski et al. 2016). These connotations are usually evoked in geo-questionnaire through a map and can be communicated by map sketching/marking and by answering questions that are triggered by map interactions. The theoretical-conceptual roots of geo-questionnaire method are broad and include planning theories, especially communicative planning (Khakee 1998), participatory geographical information systems
(PGIS) and public participation geographical information systems (PPGIS) (Dunn 2007), and critical geographical information systems (GIS) (Elwood et al. 2011). Methodically, the geo-questionnaire method is rooted in participatory mapping (Corbett, Keller 2006), social surveys and pools, and most directly in softGIS methodology developed by Kahila and Kyttä (2009), which has been used to elicit spatial distribution of people's activities and spatialized perceptions about objects and phenomena. The overarching motivation for softGIS and by extension for geo-questionnaire has been collecting and integrating local knowledge into participatory planning processes (Rantanen, Kahila 2009). 
Geo-questionnaire can be classified as a PPGIS method, albeit due to its one-way communication mode (from citizens to planners) it ranks in the middle of the communication spectrum linking citizens with planners (Carver 2001). Its primary purpose is to inform the planners and decision-makers about people's preferences and evaluations, which if taken seriously can contribute to making a planning process more inclusive, anticipate conflict among stakeholders, and provide a basis for socially acceptable, legitimate, and sustainable solutions. Several studies carried out in the last two decades sought to develop methods for eliciting public preferences by using map annotations and free-hand sketches. Early work involved sketching and annotating land development scenarios on a common base map by a small group of stakeholders in face-to-face meetings (Faber et al. 1995), incorporating local knowledge and preferences of residents into desktop GIS databases available for planners (Talen 2000), and using Web GIS to identify areas of environmental value and assessing the degree of agreement between conservation and development preferences in small stakeholder groups (Dragićević, Balram 2004). Marking and annotating analogue and digital maps has been also used as a way of collecting indigenous knowledge about land and natural resources (Kayem 2004), and mapping landscape values (Brown, Weber 2012).

Geo-questionnaires and other PGIS/PPGIS methods have been used in a variety of contexts, and processes initiated by various types of stakeholders with diverse goals and expected outcomes. In this paper, the focus is on using geo-questionnaires in processes initiated by researchers from the theoretical point of view and spatial planners from the practical point of view. That is why the geo-questionnaire will first be described as a method, then the types of data collected with geo-questionnaires, and techniques used to analyse these data will be presented. Next, the methods of recruiting survey participants and the quality of collected data will be analysed. Finally, examples of geo-questionnaire applications will be discussed. The paper is closed by recommendations for geo-questionnaires' implementation in spatial planning.

\section{Geo-questionnaire: the method description}

Geo-questionnaires belong to a broader category of Computer-Assisted Web Interviewing (CAWI) methods or Geoweb methods. They allow to simultaneously collect qualitative, quantitative and spatial data from relatively larger population samples than during face-to-face meetings. They differ from other CAWI methods in that they provide geographical context for surveys and offer functionalities enabling the input of geographic objects, i.e. points, lines and/or polygons by respondents (Jankowski et al. 2016). Geoquestionnaires typically contain multiple pages of which some are complemented with an interactive map, i.e. a map that, at a minimum, allows for panning and zooming. The data are usually contributed online in an individual unsupervised setting, but it is also possible to use geo-questionnaires in a group and/or supervised setting (e.g. Chaix et al. 2012, Bugs, Kyttä 2016). Other names used rather inconsistently in the literature to describe geo-questionnaire include "surveys that include a spatial mapping component" (Brown 2006), softGIS surveys (Kahila, Kyttä 2009), PPGIS surveys (Brown et al. 2012), interactive geolocation survey tools (Chaix et al. 2012), and online mapping surveys (Babelon et al. 2016).

As mentioned above, responses to a geo-questionnaire may contain point, line, and polygon objects sketched by participants on a map. The act of object sketching will often be used in geo-questionnaire as a trigger to present the respondent with additional questions appearing in the context windows (Fig. 1). Answers to such questions are stored in a geodatabase as feature attributes. Points are commonly used in geo-questionnaires to represent the locations of spatial variables, mostly because they are simple to interpret and use by respondents (Brown, Pullar 2012). However, in cases involving development preferences that pertain to features with defined boundaries, the use of polygons may be warranted (Jankowski et al. 2016). Some geographical features and phenomena, such as routes taken by respondents, are best represented in geo-questionnaires by lines. In some applications, instead of drawing new geographical features, the respondents may select map features provided by the geo-questionnaire 


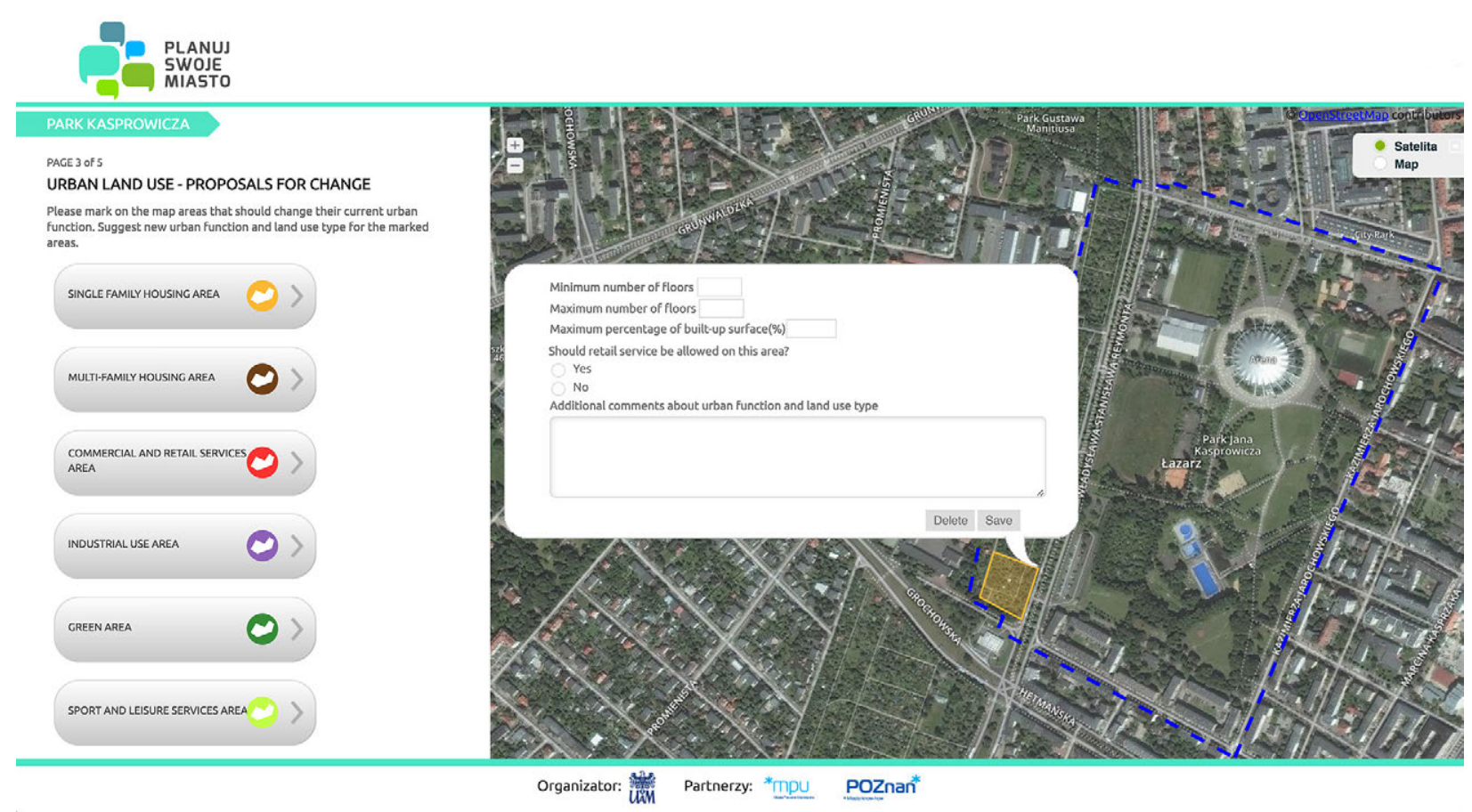

Fig. 1. Example page of a geo-questionnaire used in Kasprowicz Park case study in Poznan, Poland, described in section 6. The mapping tools on the page allow respondents to sketch polygons representing their development preferences and answer questions about preference details. The geo-questionnaire interface allows the respondents to toggle between a satellite image and a street map, pan and zoom.

designers and answer the pertinent questions (e.g. Schmidt-Thome et. al. 2013).

Data collection in geo-questionnaire is a oneway communication, in which the data flows from respondents to researchers and/or planners. The respondents usually do not see the contributions of others and there is little possibility for interaction between people. This characteristics differentiates geo-questionnaires from other online PPGIS tools such as argumentation maps (Rinner 2001), geo-discussions (Leahy, Hall 2010) or Canela PPGIS (Bugs 2010), which allow for interaction between participants.

\section{Spatial data and analysis methods}

\section{The types of spatial attributes measured with geo-questionnaires}

Geo-questionnaires are in general best suited to measure spatial attributes that are subjective in nature, and based on respondents' local knowledge, experience, perception, and opinion. Such spatial local knowledge is often ambiguous, fuzzy, and does not have distinct boundaries
(McCall, Dunn 2012). Data on spatial variables collected with geo-questionnaires and other PPGIS methods typically fall into four broad and mutually related categories:

Patterns of spatial behaviour. This category is more tangible than others, because it usually refers to visited locations, such as workplaces, services, or venues for leisure activities. Additional attributes may include travel modes used to reach a destination, routes taken, and the frequency of visits. Residential location is a related type of spatial variable that falls under the category of spatial behaviour. The location of residence is often used to provide implicit spatial reference for other non-spatial data collected with geo-questionnaires. Data on spatial behaviour and residential location have been used in transportation planning (Czepkiewicz et al. 2016a), mobility research (e.g. Salonen et al. 2014), and place-based health and wellbeing studies (e.g. Perchoux et al. 2014, Kyttä et al. 2015).

Values and valuable places. Spatial attributes in this category represent places and areas that are valuable for aesthetic, spiritual, recreational, cultural, social or other reasons (Brown 2006, Alessa et al. 2008, Pietrzyk-Kaszyńska et al. 2017). They 
may be inherently subjective and based on experiences (e.g. scenic or therapeutic values) or represent phenomena measurable with other methods (e.g. ecological or economic values). Related spatial variables include cultural ecosystem services (Brown, Fagerholm 2014), landscape attractiveness (de Vries et al. 2013), and use values (Ståhle 2006). The perceived value of places may be also indirectly derived from the patterns of use collected with geo-questionnaires (PietrzykKaszyńska et al. 2017).

Experiences and subjective evaluations. This category may include past experiences, memories, and emotions associated with locations (e.g. Pánek and Benediktsson 2017), as well as evaluations of perceived environmental quality. In softGIS methodology, such evaluations are either positive or negative and are grouped into the categories such as functional, social, aesthetic, and related to place atmosphere (Kyttä et al. 2011, 2013).

Development preferences. This category represents locations and areas where development is deemed favourable or unfavourable by the geo-questionnaire respondents (Pocewicz, Nielsen-Picus 2012, Kahila-Tani et al. 2015, Jankowski et al. 2016). Preferences may be expressed by map sketches, markings, and statements related to specific categories (e.g. housing, tourism, green areas, industrial development) or general (e.g. this area should be protected from any development). Spatial variables may also represent specific locations where a certain type of development or service should be located according to respondents (e.g. where to locate a bus stop or a playground), locations that should be improved, or objects that should be removed according to respondents. Preference variables may also pertain to specific development proposals presented in geo-questionnaire as interactive map layers (Schmidt-Thome et al. 2013, Babelon et al. 2016).

\section{Spatial analysis of geo-questionnaire data}

Data collected with a geo-questionnaire can be analysed and visualised in GIS using a variety of methods. Participant attributes may be georeferenced using their residential locations, and analysed similarly to other geodemographic data. For instance, they may be aggregated to administrative units such as districts or postal code areas and visualised in order to identify spatial patterns. The data may also be analysed (in both aggregated and disaggregated manner) using methods of exploratory and confirmatory spatial data analysis (Anselin 1999).

Geo-questionnaire data may be also used to summarize the behavioural patterns of individual respondents by calculating their activity spaces (e.g. Perchoux et al. 2014), and to build models predicting travel mode choices of individuals and households (e.g. Salonen et al. 2014). The data may be also used to calculate travel origin and destination matrices, and to study travel demand and route choices. Thus, in the context of transportation and mobility research and planning, geo-questionnaire data provide an alternative to or complement of traditional travel diaries and newer data collection methods such as GPS and mobile tracking techniques (Czepkiewicz et al. 2016a).

Spatial variables representing respondents' experiences, evaluations, values and preferences may be analysed in a disaggregated (individual) or aggregated manner (Talen 2000). When analysed individually, respondent contributions are visualised and explored one by one in a desktop or web GIS environment. When treated in aggregate, each contribution is treated in the same way and data contributed by multiple respondents are brought to a single output (e.g. a density map). With the aggregate approach, some subjectivity and individuality in data may be lost, especially when the attribute data contain the details of participants' local knowledge. Yet, the aggregated data may be preferable, for instance if the decision-making informed by the data is focused on locational choice (Talen 2000). When an in-depth insight into the respondent's contributions is necessary, a combination of aggregated and disaggregated approaches is recommended (Fig. 2).

Various GIS techniques can be used for data aggregation. Points and lines may be aggregated using simple density and kernel density estimation techniques (e.g. Alessa et al. 2008) (Fig. 2), while polygons may be aggregated by counting the polygons overlapping regularly shaped map tessellation units such as square or hexagonal cells (Jankowski et al. 2016) (Fig. 3).

Visualising the density maps can provide valuable insights into a given decision-making or research problem, but the maps can be also 


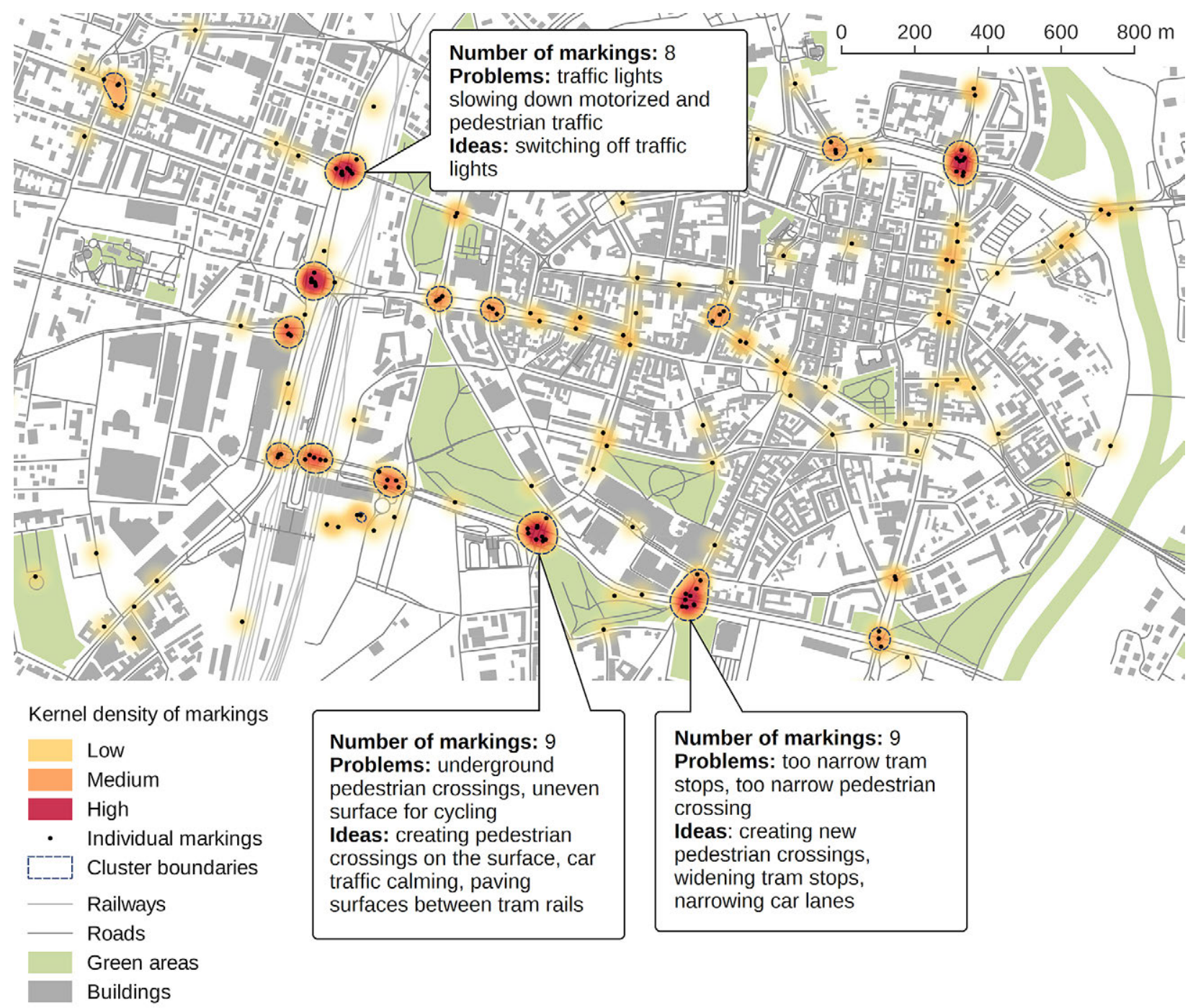

Fig. 2. Aggregated and individual analysis of point markings. The markings represent places evaluated negatively in respect to mobility in downhall Poznań. Individual point markings were aggregated with kernel density estimation using $5 \mathrm{~m}$ grid cell size and $100 \mathrm{~m}$ search radius. Then, clusters were delineated using a density threshold value, and individual answers to open-ended questions were pooled to summarize problems and solution ideas related to each cluster. Sources: topographic data (c) OpenStreetMap contributors; thematic data collected in the Local Needs Map case study.

analysed further with GIS methods. Spatial statistics and visual analytics may be used to identify high and low density clusters (Alessa et al. 2008, Brown, Pullar 2012). Distributions of spatial variables (e.g. landscape characteristics) may be also analysed using landscape ecology metrics (Brown, Reed 2012). Preferences and subjective evaluations of geo-questionnaire respondents are often combined with categorical and quantitative data such as land use/land cover maps and other derivatives of remote sensing data. For instance, the geo-questionnaire derived social values and use patterns may be spatially joined with land use data or remote sensing images to evaluate urban green spaces (Brown et al. 2014a, PietrzykKaszyńska et al. 2017), create sociotope maps (Ståhle 2006) or identify socio-ecological hotspots (Alessa et al. 2008).

Spatial variables that represent development preferences may be aggregated into agreementdisagreement maps depicting areas, in which favourable or unfavourable opinions dominate (Jankowski et al. 2016, Fig. 4). These maps may be further combined with spatial variables representing social values to show the locations of potential conflict (Brown, Raymond 2014, KahilaTani et al. 2015). Such maps allow to identify areas and locations, in which the high level of 


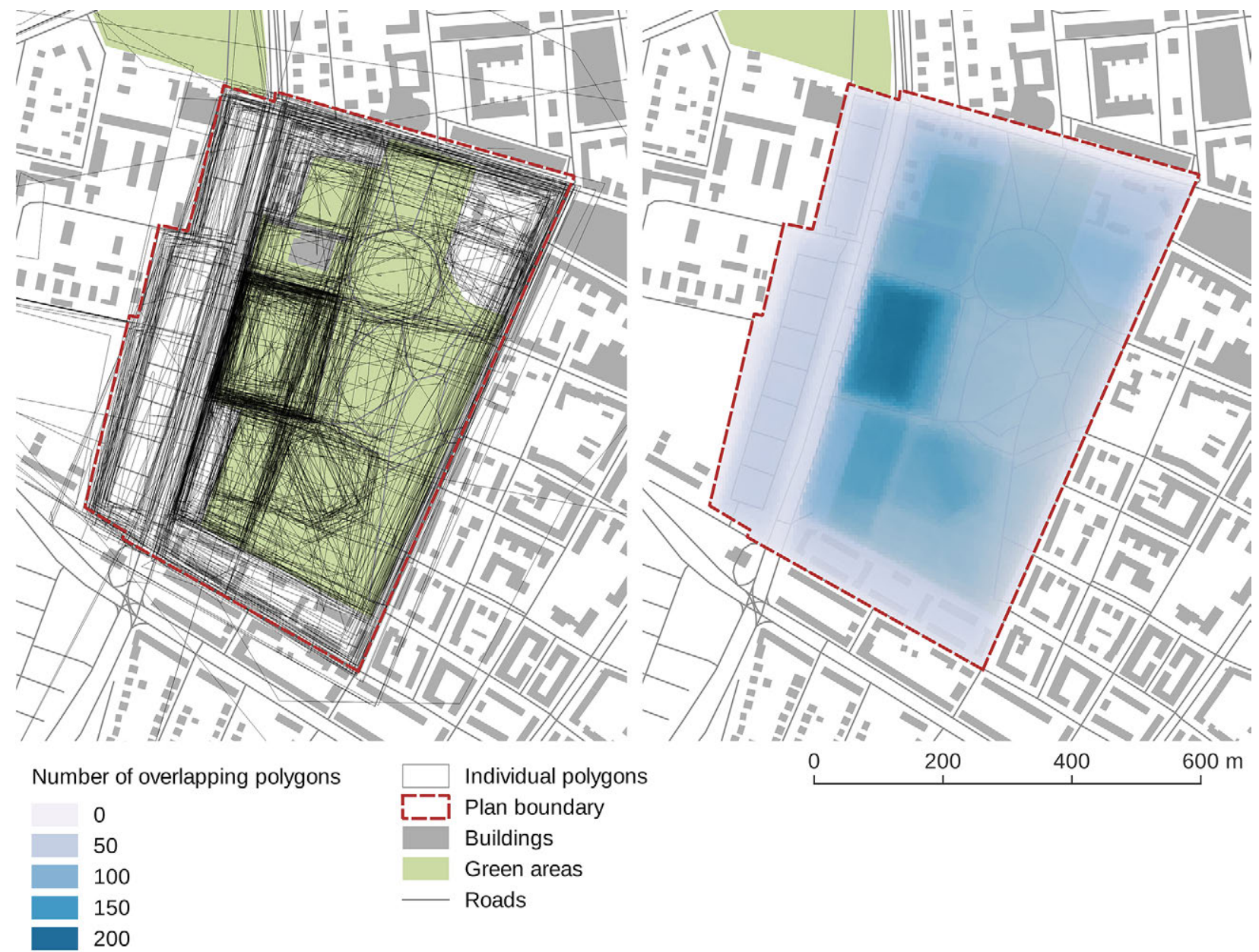

Fig. 3. Aggregated analysis of polygon markings. The polygons represent areas that, according to the geoquestionnaire respondents, should change its function to sport and recreation facilities. The map frame on the left presents raw polygon features as sketched by participants. The map frame on the right presents an aggregated map, in which the raster cell values represent the number of polygons overlapping each cell. Sources: topographic data (C) OpenStreetMap contributors; thematic data collected in the Kasprowicz Park case study.

subjective value overlaps with the high proportion of views favourable for development. The aggregated preference maps may be also combined with locations of known development proposals or initiatives, and enable planners to anticipate the areas of potential conflict and disagreement during the planning process.

\section{Participant selection and recruitment}

Geo-questionnaires and related PPGIS methods have been applied in various contexts and served diverse stakeholder needs. Most broadly, the geo-questionnaire applications may be divided into those related to academic research and the ones related to the non-statutory collecting of public preferences and opinions informing spatial planning. In academic research, geo-questionnaire data are often expected to allow the generalization of preferences and behavioural patterns from a sample to broad population. In such context, probability sampling is preferred over voluntary or other non-probabilistic sampling methods used to identify and recruit potential respondents. However, the use of geo-questionnaires as a public participation method requires a more nuanced consideration of the question of who participates in data collection (Schlossberg, Shuford 2005).

Random sampling used to recruit participants allows for the data collected through PPGIS applications to be interpreted as representative of the views of general public, and provides a silent majority with an opportunity to inform the 

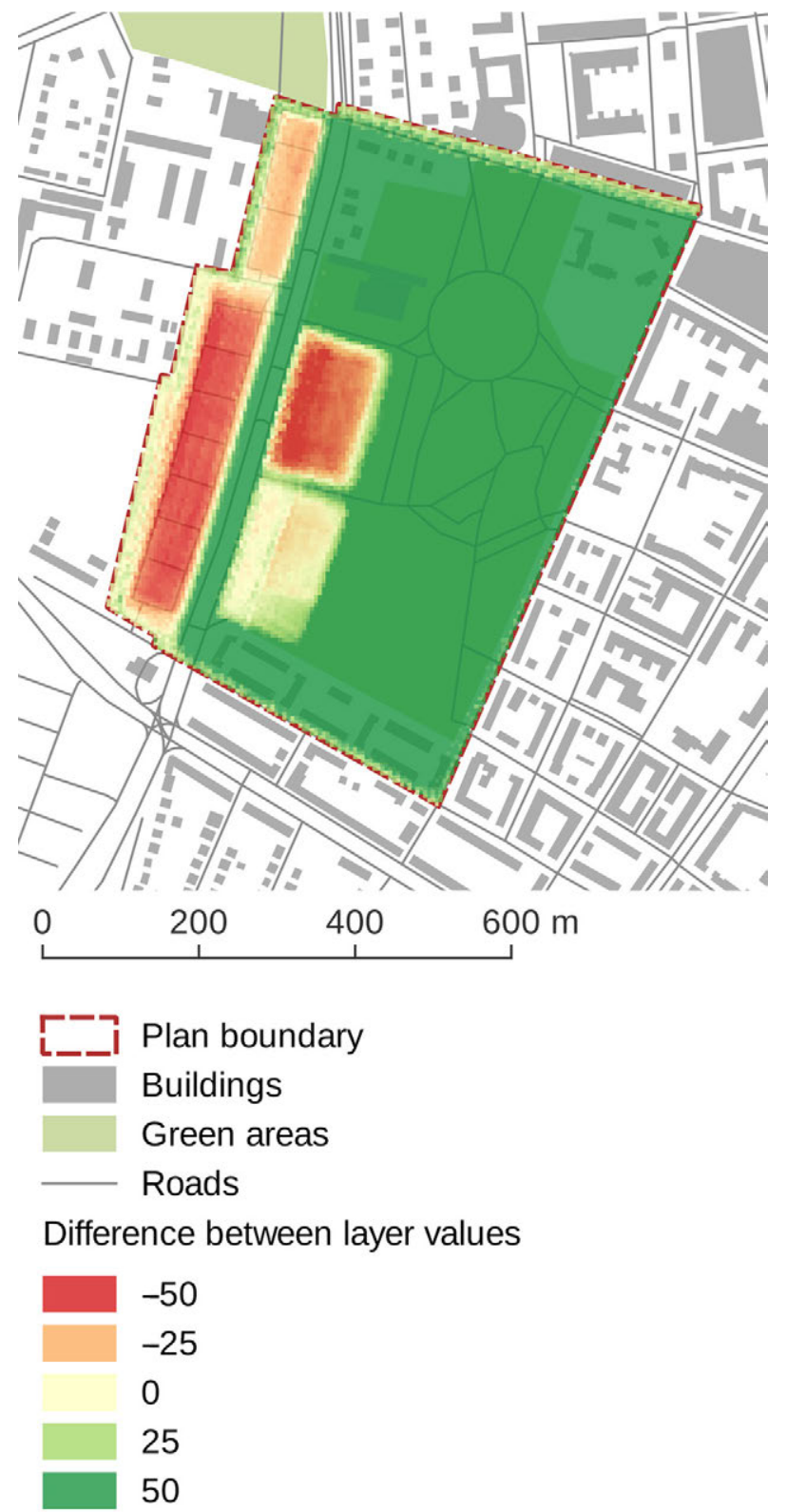

Fig. 4. Agreement-disagreement map. The map was created by calculating the difference between two aggregate maps with polygons representing preferences: one in favour of the preservation of current function, and the other in favor of function change. Negative values on the map represent areas where views in favour of function change dominate,

positive values represent areas where views in favour of function preservation dominate. Sources: topographic data (C) OpenStreetMap contributors; thematic data collected in the Kasprowicz Park case study.

decision-making. In many public participation methods, in which the participants self-select, such as public meetings, only the most vocal and active citizens, including organised interest groups, are represented and many other voices are never heard (Innes, Booher 2004). Similar bias may result from using voluntary sampling in PPGIS data collection thereby influencing the quality of results (Brown et al. 2014a). However, participatory planning approaches often require that all stakeholders have an equal opportunity to take part in data collection, and planners often favour voluntary over random sampling (KahilaTani et al. 2015). From the planners' perspective, voluntary sampling in PPGIS invites the participation of everyone who is interested, is less cumbersome than random sampling to carry out, and costs less to implement. Moreover, the most active and interested participants are often willing to devote more time and effort to mapping activities, therefore providing higher quality data (Brown 2012b).

Brown and Kyttä (2014) see the choice of sampling methods as one of key issues in PPGIS and call for further research on their effects on participation rates and data quality. Other researchers have called for the concurrent use of probability and voluntary sampling to study the effect of sampling methods (Brown, Reed 2009) on the quality of public participation (Brown et al. 2014a). Another important issue for geo-questionnaire data collection is the quality of data required to effectively inform planning (Brown, Kyttä, 2014, Czepkiewicz et al. 2016b).

\section{Data quality}

The criteria for evaluating quality of data obtained from geo-questionnaire depend on the goal and the context of geo-questionnaire use. Some of the criteria are the same as in other survey methods, others are specific to geo-questionnaires and PPGIS methods. The quality criteria can be divided into internal and external (Lechner et al. 2014, Devillers et al. 2010).

\section{Internal data quality}

Internal data quality pertains to the degree, to which the attributes have been correctly measured, interpreted and represented by data. In survey research, such criteria include construct validity, logical consistency, and completeness (Lechner et al. 2014). Additionally, in reference 
Table 1. Description of selected geo-questionnaire cases in Poland.

\begin{tabular}{|c|c|c|c|c|c|}
\hline Case & City & Year & Topic & Participants & Recipients \\
\hline Kasprowicz Park & $\begin{array}{c}\text { Poznań } \\
\text { (population } \\
545,000)\end{array}$ & 2015 & $\begin{array}{l}\text { Local urban } \\
\text { planning }\end{array}$ & $\begin{array}{l}\text { Local area residents } \\
\text { and users } \\
(\mathrm{N}=1,009)\end{array}$ & $\begin{array}{c}\text { Poznań Urban Planning } \\
\text { Office }\end{array}$ \\
\hline Local needs map & $\begin{array}{c}\text { Poznań } \\
\text { (population } \\
545,000)\end{array}$ & 2016 & $\begin{array}{l}\text { Downtown urban } \\
\text { renewal }\end{array}$ & $\begin{array}{l}\text { Downtown } \\
\text { residents and users } \\
(\mathrm{N}=709)\end{array}$ & $\begin{array}{l}\text { Poznań City Hall, Poznań } \\
\text { neighborhood councils }\end{array}$ \\
\hline $\begin{array}{l}\text { Sustainable public } \\
\text { transportation model }\end{array}$ & $\begin{array}{c}\text { Łódź } \\
\text { (population } \\
701,000)\end{array}$ & 2016 & $\begin{array}{c}\text { Public } \\
\text { transportation } \\
\text { planning } \\
\end{array}$ & $\begin{array}{c}\text { Public } \\
\text { transportation users } \\
(\mathrm{N}=2,387)\end{array}$ & Łódź City Hall \\
\hline $\begin{array}{l}\text { New Rokietnica } \\
\text { centre }\end{array}$ & $\begin{array}{c}\text { Rokietnica } \\
\text { (population } \\
5,500)\end{array}$ & 2016 & $\begin{array}{l}\text { Suburban town } \\
\text { planning }\end{array}$ & $\begin{array}{l}\text { Rokietnica residents } \\
\qquad(\mathrm{N}=435)\end{array}$ & $\begin{array}{l}\text { Rokietnica Municipal Office, } \\
\text { land use plan designer }\end{array}$ \\
\hline
\end{tabular}

to spatial data the criteria include positional and attribute accuracy (Goodchild, Li 2012).

Construct validity and logical consistency refer to how well spatial variables collected with geo-questionnaires reflect phenomena they are intended to measure, and are largely dependent on the survey design and to a lesser extent on participant characteristics (Jankowski et al. 2016). Locational accuracy in PPGIS is influenced by the nature of spatial variable itself (e.g. its ambiguity), instructions provided to participants, quality of mapping environment (e.g. background map, navigation tools), map zoom level, as well as the respondents' mapping skills and familiarity with the study area (Brown 2012b). Some PPGIS data do not require high spatial accuracy because the participants mark regions and places with undefined boundaries to begin with (Brown, Pullar 2012). Attribute accuracy in PPGIS is closely related to locational accuracy, since it may result from miss-attributing certain characteristics of geographical features as well as from misplacing them. The attribute accuracy may be validated in some cases by the comparison with expert-derived data. Such comparison is not always possible, and the researchers have suggested proxy measures of PPGS data quality, such as the amount of participant effort put into mapping activities (Brown 2012b).

\section{External data quality}

External data quality relates to how well knowledge and values of the target population group(s) are represented in geo-questionnaire data. It is as important in academic research as it is in the practical uses of geo-questionnaire data. In the former, the main question refers to the ability to generalize findings to a target population, whereas in the latter the question pertains to whose perspective has stronger influence on decisions.

\section{Social representativeness}

Social representativeness refers to how well various social groups, and by extension their values and perspectives, are represented in the data. It is usually measured by comparing basic socio-demographic characteristics (e.g. age, gender, education, ethnicity or employment status), between the sample and the population. As a predominantly online data collection method, geo-questionnaire is subject to digital divide. Therefore, any use of the method may reproduce inequalities in access to and the ability of using information and communication technologies by a given social group. One way to alleviate socio-demographic biases may be to use the supervised data collection mode in workshop settings with the recruitment based on quota sampling to ensure equal participation of social groups, and to facilitate those participants who have a low level of Web browsing and mapping skills. Biases related to browsing and mapping skills may also be alleviated by user-centric design (Haklay, Tobón 2003, Bugs 2012), and tailoring interfaces to the needs of specific groups, such as children (Kahila, Kyttä 2009) or older adults (Gottwald et al. 2016).

\section{Spatial representativeness}

An aspect of data representativeness, which is rarely evaluated in other social survey methods is related to the spatial distribution of participants. If the spatial distribution of respondent sample does not reflect well the spatial pattern of target 
group, it may be the source of bias in the analysis of data collected with geo-questionnaire. Participants' distribution is typically represented by locations of their residences and it may be compared with the spatial pattern of area residents. In PPGIS, the level of knowledge about places affects how spatial variables are mapped, and the familiarity with locations closer to one's place of residence is typically higher than with locations that are farther away (Brown, Reed 2009). In cases of attributing values and desirable land uses to specific locations, the distance to the domicile might influence the assigned values/preferred land use categories due to spatial discounting: place value and attachment develop with proximity and familiarity, and people prefer to have positive aspects close to their homes while keeping the negative aspects away (Brown et al. 2002, Pocewicz, Nielsen-Pincus 2013, Brown, Kyttä 2014). Spatial representativeness may be assessed by comparing the distribution of respondents with the pattern of plan area residents aggregated to spatial units (Czepkiewicz et al. 2016b).

\section{Application examples}

Geo-questionnaires and similar PPGIS methods have been applied to elicit public preferences on various subjects and at various spatial scales in a number of countries including Finland (Kahila, Kyttä 2009, Schmidt-Thomé et al. 2013, Kahila-Tani et al. 2015), Sweden (Babelon et al. 2016), Iceland (Pánek, Benediktsson 2017), Czech Republic (Pánek et al. 2017), USA (Alessa et al. 2008, Brown, Reed 2009, Schmidt-Thomé et al. 2014), New Zealand (Brown, Weber 2012), Portugal and Brazil (Bugs, Kyttä 2016), and Australia (Brown 2012a). A more comprehensive review of PPGIS data collection cases in academic research can be found in Brown and Kyttä (2014). Here, we briefly present four recent cases of geo-questionnaire applications conducted in Poland in 2015 and 2016, initiated by the authors as part of applied research projects, and related to ongoing urban planning processes.

Each of the cases is described below in terms of its context, topical content, and situation in urban planning process:

Kasprowicz Park case involved collecting public input for the formulation of local land use plan for a mixed-use area in Poznań inner city, featuring an urban park, allotment gardens, single- and multi-family housing, as well as commercial and public services. The area also features brownfields (e.g. abandoned stadium, unfinished construction site), on which a real estate developer proposed to build residential high-rises. The proposal was met with resident disapprovals and the local land use plan was initiated to prevent an unwanted development. The geo-questionnaire was applied as part of non-mandatory public participation process in parallel to mandatory public consultations (Kaczmarek, Wójcicki 2016). The data collection with geo-questionnaire was carried out after the first public meeting, but before formulating the draft plan and the second public meeting. The geo-questionnaire included questions about the patterns of spatial behaviour, development, and preservation preferences. The data represented in the form of map sketches and text were aggregated, summarized in a report, and used in formulating a draft plan, which was later presented in the meetings with stakeholders (residents, neighbourhood council members, City Hall officials). The Kasprowicz Park case is described in detail by Jankowski et al. (2016, 2017a).

Local needs map case was part of the city centre renewal program initiated by the Poznan City Council. The program involves a biannually updated list of local needs and investment proposals, prepared and used by the city neighbourhood councils. In 2016, a geo-questionnaire was used to broaden the base of participants to downtown residents and users, and increase data volume and quality. The city centre in Poznań is a densely built, mostly historic district with 122,000 residents living on 1,680 ha. The geo-questionnaire was applied in an initial phase of environmental quality evaluation. Its content included questions aimed at eliciting the patterns of spatial behaviour (travel and public space use) and perceived environmental quality (e.g. negatively evaluated places and areas, satisfaction with environmental quality and accessibility of services). The report with geo-questionnaire results was followed by an investment selection process and workshops conducted in each neighbourhood. The City Hall officials and the neighbourhood council members who vote on neighbourhood spending plans were the main recipients of geo-questionnaire 
data. The data analysis process for this case study is described in more detail in Bąkowska et al. (2016).

Sustainable public transportation model case was conducted in Łódź, the second largest city in Poland with population 701,000. The target population of geo-questionnaire data collection were the users of public transportation system in the city. The geo-questionnaire content included questions about the patterns of travel behaviour (origins and destinations, frequencies, travel modes), perceived environmental quality (evaluation of public transportation infrastructure, satisfaction with public transportation access and quality), and locational preferences of Park \& Ride stations. The data collection was conducted at the end of planning process, following the completion of transportation plan draft, to facilitate amendments to the draft based on public input, and to improve communication between the residents and the City Hall unit responsible for the plan formulation. The data collection and analysis for this case study is described in Bąkowska et al. (2016) and Czepkiewicz et al. (2016a).

New Rokietnica Centre case was conducted in Rokietnica - a town (population ca 5,500) located in the suburban fringe of Poznań metropolitan region (population ca 800,000). Rokietnica has quickly increased its population during Poznan suburbanization process taking place since the mid-1990s. A new local land use plan for the town centre was part of the suburban retrofitting initiative by the local government, aiming to introduce central functions, dense development, and mixed uses on the currently undeveloped area. The geo-questionnaire content included questions aimed at eliciting the patterns of spatial behaviour, the resident attitudes towards the undeveloped area, and development preferences (both spatially explicit and general). The data collection comprised non-mandatory consultations with the town residents and it was conducted before preparing the draft plan. The main recipients of collected data were the City Hall officials and a private urban design company responsible for the plan preparation. At the time of this writing, the draft plan has been prepared incorporating the resident development preferences, and is ready to be presented and discussed online using an interactive discussion tool, called geo-discussion (Jankowski et al. 2017b, 2018), that links a structured discussion forum with an interactive map. The New Rokietnica Centre case, along with the other cases, is described in more detail in Bąkowska et al. (2016).

\section{Recommendations for geo- questionnaire application in spatial planning}

The majority of PPGIS applications reported in different journals so far have involved prototypes developed and tested by researchers for academic purposes and with little or no linkages to actual planning processes (e.g. Rinner, Bird 2009, Bugs et al. 2010). More recently, several cases of PPGIS use in municipal planning have been reported (Kahila-Tani et al. 2015, Jankowski et al. 2016), and some commercial and open-source tools have been commissioned and applied by municipalities in Sweden, Finland, and Poland ${ }^{1}$. According to Babelon et al. (2016), the rate of practical implementations of geo-questionnaires and other softGIS / PPGIS methods is already outpacing academic research on the topic. The implementation rate may continue to grow, thus increasing the demand for both hands-on knowledge and best practices in geo-questionnaire applications. Apart from data quality and participant recruitment issues discussed above, there are other issues related to geo-questionnaire applications in planning, that require the attention of both professionals seeking to implement the method and researchers willing to contribute to the field. Building upon Babelon et al. (2016) framework, we briefly summarize the main socio-technical aspects of geo-questionnaire implementation in planning:

Tool design and affordances: in order to provide high data quality, representativeness, and participant satisfaction, PPGIS tools need user-friendly interfaces, that are compatible across devices, and have good balance between functionality and simplicity (Haklay, Tobón 2003, Bugs 2012). Geo-questionnaire content should be short and simple, and allow unambiguous data input (Brown, Kyttä 2014, Jankowski et al. 2016).

\footnotetext{
Examples include Geopanelen and Bästa Platsen in Sweden, Maptionnaire and eHarava in Finland, and Geoankieta in Poland.
} 
The tool functions should be customized to fit its purpose and role in the planning process, and to enhance the quality of collected data.

Situation in planning process: this aspect refers to how the geo-questionnaire use is defined and what role does it have in planning process. Most researchers agree that data obtained from geo-questionnaires should be used at the beginning of planning processes in order to inform plan designs by taking into account preferences and knowledge of the public, and to anticipate and possibly avert conflict (Brown, Raymond 2014, Kahila-Tani et al. 2015, Jankowski et al. 2016). Other PPGIS methods may be suitable for later planning phases, which have different needs for public input than an initial phase. Geoquestionnaires may also be used in parallel with other PPGIS and traditional public participation methods (e.g. using geo-questionnaire results during public meetings or using different PPGIS configurations in different planning phases).

Software development and sustainability: PPGIS uptake in urban planning, including geo-questionnaires, is closely related to software affordability, reliability, and flexibility. These issues are related to how PPGIS software tools are designed, developed and maintained. Such issues as software licensing (e.g. proprietary vs. free and open source), research and development models, funding available for software development (e.g. government funded or commercial), are important for the sustainable implementation of PPGIS and influence the ability to develop new software functions and maintain software compatibility with continuously evolving devices, Web standards, application programming interfaces (APIs), and spatial data infrastructures.

Organizational capacity and context: PPGIS implementations require municipalities to allocate resources such as budget, time, and staff. They also require certain level of knowledge on how to use methods and tools (e.g. how to prepare survey content and analyse data). The willingness to allocate municipal resources to geo-questionnaire implementation depends on the perception of its costs and benefits. It creates the need for the evaluation of outcomes and for assessing whether or not the obtained data improves the quality of decisions and participation processes, and contributes to creating plans that are better suited to the needs of local communities than plans created without public input. PPGIS uptake is also closely related to legal requirements for public participation, available funding, professional and organizational cultures, as well as the social acceptance of such participation methods (Slotterback 2011, Brown 2012a).

Governance and social outcomes: GISsupported public participation processes require careful consideration of their quality and emergent social outcomes (Sieber 2006). PPGIS data formats and functionalities frame public participation and data in a way that may both support and hinder diverse representation of places and values (McCall, Dunn 2012). Public input through methods such as geo-questionnaire is usually expected to influence planning outcomes (KahilaTani et al. 2015, Jankowski et al. 2016) but it does not necessarily move a given planning process up the rungs of participation ladder (Arnstein 1969) or across participation spectrum (IAP2 2014). Researchers and practitioners should pay attention to whether PPGIS supports meaningful and diverse interactions (e.g. Nyerges, Aguirre 2011) and whether its use fulfils normative requirements of good governance (McCall, Dunn 2012).

An in-depth description of the geo-questionnaire, as well as geo-discussion, can be found in two separate elaborations, extensively discussing all the details of both Geoweb applications (Jankowski et al. 2017b, 2018).

\section{Conclusion}

The article's aim has been to provide an overview of geo-questionnaire as a PPGIS method for eliciting spatial local knowledge and public preferences. We have discussed geo-questionnaire data content, data visualisation, aggregation and analysis methods. We have reviewed several issues underpinning the applications of geo-questionnaires in academic research and in municipal planning, including respondent selection and recruitment, data quality, and data representativeness. To substantiate the discussion of method with application examples we have briefly described four recent geo-questionnaire use cases from Poland. The described case studies show the versatility of geo-questionnaire as a method for collecting data on public preferences, behavioural patterns, and local knowledge that can be 
relevant for planning practice in a variety of domains including land use, public transportation, green spaces, and urban functions, to name a few. Whether or not this particular method of public input becomes more broadly adopted by planners will depend on the perceived and real costs of deploying geo-questionnaires vs. the value of collected data, and on public perception of the effectiveness of geo-questionnaire to have their preferences incorporated in the decision-making outcomes.

\section{Acknowledgments}

The research reported in the article and the case studies were conducted in two projects. The Kasprowicz Park case study was part of the project An Experimental Study of Public Participation in Planning Decision Making Using Web-based Geographic Information System, funded by the National Science Centre in Poland; the funding decision DEC-2012/05/B/HS4/03850. The remaining case studies were part of the project Geoportal supporting public participation in spatial planning funded by the National Research and Development Centre in Poland; contract number PBS3/A9/39/2015. The authors gratefully acknowledge the support of Poznan City Hall, Łódź City Hall, Rokietnica Municipal Office, and Poznań Urban Planning Office, and the cooperation of neighbourhood councils in Poznań. Figures in the article use data provided by OpenStreetMap contributors, participants of geo-questionnaire case studies, and abovementioned municipalities. Finally, authors thank reviewers for comments on the earlier version of the paper.

\section{References}

Alessa L., Kliskey A., Brown G., 2008. Social-ecological hotspots mapping: A spatial approach for identifying coupled social-ecological space. Landscape and Urban Planning 85(1): 27-39. DOI: 10.1016/j.landurbplan.2007.09.007.

Anselin L., 1998. Interactive techniques and exploratory spatial data analysis. In: P. Longley, M. Goodchild, D. Maguire, D. Rhind (eds.), Geographical Information Systems: Principles, Techniques, Management and Application. John Wiley \& Sons, new York: 253-266.

Arnstein S.R., 1969. A Ladder of Citizen Participation. Journal of the American Planning Association 35(4): 216-224. DOI: 10.1080/01944366908977225.
Babelon I., Ståhle A., Balfors B., 2016. Toward Cyborg PPGIS : exploring socio-technical requirements for the use of web-based PPGIS in two municipal planning cases, Stockholm region, Sweden, Journal of Environmental Planning and Management 60(8): 1366-1390. DOI: 10.1080/09640568.2016.1221798.

Bąkowska E., Kaczmarek T., Jankowski P., Zwoliński Zb., Mikuła Ł., Czepkiewicz M., Brudka C., 2016. Geo-questionnaire in urban planning - preliminary results of the experimental application in Poland. Rozwój Regionalny $i$ Polityka Regionalna 35: 37-54.

Brown G., 2006. Mapping Landscape Values and Development Preferences: a Method for Tourism and Residential Development Planning. International Journal of Tourism Research 113(8): 101-113.

Brown G., 2012a. Public Participation GIS (PPGIS) for Regional and Environmental Planning: Reflections on a Decade of Empirical Research. URISA Journal 25(2): 7-18.

Brown G., 2012b. An empirical evaluation of the spatial accuracy of public participation GIS (PPGIS) data. Applied Geography 34: 289-294. DOI: 10.1016/j.apgeog.2011.12.004.

Brown G., Fagerholm N., 2014. Empirical PPGIS/PGIS mapping of ecosystem services: A review and evaluation. Ecosystem Services 13: 119-133. DOI: 10.1016/j.ecoser.2014.10.007.

Brown G., Kelly M., Whitall D., 2014a. Which "public"? Sampling effects in public participation GIS (PPGIS) and volunteered geographic information (VGI) systems for public lands management. Journal of Environmental Planning and Management 57(2): 190-214. DOI: 10.1080/09640568.2012.741045.

Brown G., Kyttä M., 2014. Key issues and research priorities for public participation GIS (PPGIS): A synthesis based on empirical research. Applied Geography 46: 122-136. DOI: 10.1016/j.apgeog.2013.11.004.

Brown G., Pullar D.V., 2012. An evaluation of the use of points versus polygons in public participation geographic information systems using quasi-experimental design and Monte Carlo simulation. International Journal of Geographical Information Science 26(2): 231-246. DOI: 10.1080/13658816.2011.585139.

Brown G., Raymond C.M., 2014. Methods for identifying land use conflict potential using participatory mapping. Landscape and Urban Planning 122: 196-208. DOI: 10.1016/j.landurbplan.2013.11.007.

Brown G., Reed P., 2009. Public Participation GIS: A New Method for Use in National Forest Planning. Forest Science 55(2): 166-182.

Brown G., Reed P., 2012. Social Landscape Metrics: Measures for Understanding Place Values from Public Participation Geographic Information Systems (PPGIS). Landscape Research 37(1): 73-90. DOI: 10.1080/01426397.2011.591487.

Brown G., Reed P., Harris C.C., 2002. Testing a place-based theory for environmental evaluation: an Alaska case study. Applied Geography 22: 49-76.

Brown G., Schebella M.F., Weber D., 2014b. Using participatory GIS to measure physical activity and urban park benefits. Landscape and Urban Planning 121: 34-44. DOI: 10.1016/j.landurbplan.2013.09.006.

Brown G., Weber D., 2011. Public Participation GIS: A new method for national park planning. Landscape and Urban Planning 102(1): 1-15. DOI: 10.1016/j.landurbplan.2011.03.003.

Brown G., Weber D., 2012. A place-based approach to conservation management using public participation GIS 
(PPGIS). Journal of Environmental Planning and Management 56(4): 1-19. DOI: 10.1080/09640568.2012.685628.

Brown G., Weber D., Zanon D., De Bie K., 2012. Evaluation of an online (opt-in) panel for public participation geographic information systems surveys. International Journal of Public Opinion Research 24(4): 534-545. DOI: 10.1093/ijpor/eds001

Bugs G., 2012. Assessment of Online PPGIS Study Cases in Urban Planning. In: B. Murgante, O. Gervasi, S. Misra, N. Nedjah, A.M.A.C. Rocha, D. Taniar, B.O. Apduhan (eds.), Computational Science and Its Applications - ICCSA 2012, Springer: 477-490. DOI: 10.1007/978-3-642-311253_36.

Bugs G., Granell C., Fonts O., Huerta J., Painho M., 2010. An assessment of Public Participation GIS and Web 2.0 technologies in urban planning practice in Canela, Brazil. Cities 27(3): 172-181. DOI: 10.1016/j.cities.2009.11.008.

Bugs G., Kyttä M., 2016. Public Perception Spatial Data from the PPGIS Jaguarão Experiment. In: S. Konomi, G. Roussos (eds.), Enriching Urban Spaces with Ambient Computing, the Internet of Things, and Smart City Design, IGI Global: 257-278. DOI: 10.4018/978-1-5225-0827-4.ch013.

Carver S. 2001. Participation and Geographical Information: a position paper. Position Paper for the ESF-NSF Workshop on Access to Geographic Information and Participatory Approaches Using Geographic Information, Spoleto, 6-8 December

Chaix B., Kestens Y., Perchoux C., Karusisi N., Merlo J., Labadi K., 2012. An interactive mapping tool to assess individual mobility patterns in neighborhood studies. American Journal of Preventive Medicine 43(4): 440-450. DOI: 10.1016/j.amepre.2012.06.026.

Corbett J., Keller P., 2006. An analytical framework to examine empowerment associated with participatory geographic information systems (PGIS). Cartographica 40(4): 91-102.

Czepkiewicz M., Brudka C., Jankowski P., Kaczmarek P., Zwoliński Zb., Mikuła Ł., Bąkowska E., Młodkowski M., Wójcicki M., 2016a. Public Participation GIS for sustainable urban mobility planning: methods, applications and challenges. Rozwój Regionalny i Polityka Regionalna 35: 9-35.

Czepkiewicz M., Jankowski P., Młodkowski M., 2016b. Geo-questionnaires in urban planning: recruitment methods, participant engagement, and data quality. Cartography and Geographic Information Science 44(6): 551-567. DOI: $10.1080 / 15230406.2016 .1230520$.

Devillers R., Stein A., Bedard Y., Chrisman N., Fisher P., Shi W., 2010. Thirty years of research on spatial data quality: achievements, failures, and opportunities. Transactions in GIS 14(4): 387-400.

Dragićević S., Balram S., 2004. A Web GIS collaborative framework to structure and manage distributed planning processes. Journal of Geographical Systems 6(2): 133-153.

Dunn C.E., 2007. Participatory GIS - a people's GIS? Progress in Human Geography 31(5): 616-637.

Elwood S., Schuurman N., Wilson M.W., 2011. Critical GIS. In: T.L. Nyerges, H. Couclelis, R. McMaster (eds.), The SAGE Handbook of GIS and Society, SAGE, Los Angeles: 87-106.

Faber B.G., Wallace W., Cuthbertson J., 1995. Advances in Collaborative GIS for Land-Resource Negotiation. The Proceedings of the GIS'95 Ninth Annual Symposium on Geographic Information Systems Vancouver, B.C. GIS World Inc. 1: 183-189.
Goodchild M.F., Li L., 2012. Assuring the quality of volunteered geographic information. Spatial Statistics 1: 110120. DOI: $10.1016 /$ j.spasta.2012.03.002.

Gottwald S., Laatikainen T.E., Kyttä M., 2016. Exploring the usability of PPGIS among older adults: challenges and opportunities. International Journal of Geographical Information Science 30(12): 2321-2338. DOI: 10.1080/13658816.2016.1170837.

Haklay M., Tobón C., 2003. Usability Evaluation and PPGIS: towards a user-centred design approach. International Journal of Geographical Information Science 17(6): 577-592.

IAP2 [International Association of Public Participation], 2014. IAP2 Spectrum of Public Participation. International Association for Public Participation. Online: www.iap2. org/resource/resmgr/foundations_course/IAP2_P2_ Spectrum_FINAL.pdf (accessed 19 August 2018)

Innes J.E., Booher D.E., 2004. Reframing Public Participation: Strategies for the 21st Century. Planning Theory \& Practice 5(4): 419-436.

Jankowski, P., Czepkiewicz, M., Młodkowski, M., Zwoliński, Zb. (2016). Geo-questionnaire: A Method and Tool for Public Preference Elicitation in Land Use Planning Piotr. Transactions in GIS 20(6): 903-924. DOI: 10.1111/ tgis.12191

Jankowski P., Czepkiewicz M., Młodkowski M., Zwoliński Zb., Wójcicki M., 2017a. Evaluating the scalability of public participation in urban land use planning: A comparison of Geoweb methods with face-to-face meetings. Environment and Planning B: Urban Analytics and City Science. DOI: $10.1177 / 2399808317719709$.

Jankowski P., Kaczmarek T., Zwolinski Zb., Bakowska-Waldmann E., Brudka C., Czpkiewicz M., Mikuła Ł., Młodkowski M., 2018. Zastosowanie aplikacji geoankiety $i$ geodyskusji w partycypacyjnym planowaniu przestrzennym - dobre praktyki. Bogucki Wydawnictwo Naukowe, Poznań: 1-81.

Jankowski P., Kaczmarek T., Zwoliński Zb., Mikuła Ł., Wójcicki M., Bąkowska E., Czepkiewicz M., Młodkowski M., Brudka C., 2017b. Narzędzia internetowe w konsultacjach społecznych w planowaniu przestrzennym. Idea, obszary zastosowań $i$ wdrażanie. Wydawnictwo Naukowe UAM, Poznań: 1-58.

Kaczmarek T., Wójcicki M., 2016. Participation in social consultations on physical planning documents. The case of Poznań City. Quaestiones Geographicae 35(2): 71-81.

Kahila M., Kyttä M., 2009. SoftGIS as a bridge builder in collaborative urban planning. In: S. Geertman, J. Stillwell (eds.), Planning Support Systems: Best Practices and New Methods, Springer: 389-412.

Kahila-Tani M., Broberg A., Kyttä M., Tyger T., 2015. Let the Citizens Map-Public Participation GIS as a Planning Support System in the Helsinki Master Plan Process. Planning Practice \& Research 31(2): 195-214. DOI: 10.1080/02697459.2015.1104203.

Khakee A. 1998. Evaluation and Planning: two inseparable concepts. Town Planning Review 69(4): 359-374.

Kyttä M., Broberg A., Haybatollahi M., Schmidt-Thomé K., 2015. Urban happiness: context-sensitive study of the social sustainability of urban settings. Environment and Planning B: Planning and Design 47: 1-24. DOI: 10.1177/0265813515600121.

Kyttä M., Broberg A., Tzoulas T., Snabb K., 2013. Towards contextually sensitive urban densification: Location-based softGIS knowledge revealing perceived resi- 
dential environmental quality. Landscape and Urban Planning 113: 30-46. DOI: 10.1016/j.landurbplan.2013.01.008.

Kyttä M., Kahila M., Broberg A., 2011. Perceived environmental quality as an input to urban infill policy-making. URBAN DESIGN International 16(1): 19-35. DOI: 10.1057/ udi.2010.19.

Leahy M., Hall G.B., 2010. Using open source software components to implement a modular Web 2.0 design for map-based discussions. International Journal of Open Source Software and Processes 2(3): 30-47.

Lechner A.M., Raymond C.M., Adams V.M., Polyakov M., Gordon A., Rhodes J.R., Mills M., Stein A., Ives C.D., Lefroy E.C., 2014. Characterizing spatial uncertainty when integrating social data in conservation planning. Conservation Biology 28(6): 1497-1511. DOI: 10.1111/cobi.12409.

McCall M.K., Dunn C.E., 2012. Geo-information tools for participatory spatial planning: Fulfilling the criteria for "good" governance? Geoforum 43(1): 81-94. DOI: 10.1016/j.geoforum.2011.07.007.

Nyerges T., Aguirre R.W., 2011. Public Participation in Analytic-Deliberative Decision Making: Evaluating a LargeGroup Online Field Experiment. Annals of the Association of American Geographers 101(3): 37-41.

Pánek J., Benediktsson K., 2017. Emotional mapping and its participatory potential: Opinions about cycling conditions in Reykjavík, Iceland. Cities 61(1): 65-73. DOI: 10.1016/j.cities.2016.11.005.

Pánek J., Pászto V., Marek L., 2017. Mapping Emotions: Spatial Distribution of Safety Perception in the City of Olomouc. In. I. Ivan, A. Singleton, J. Horák, T. Inspektor (eds.) The Rise of Big Spatial Data, Lecture Notes in Geoinformation and Cartography: 211-224. DOI: 10.1007/978-3319-45123-7.

Perchoux C., Kestens Y., Thomas F., Hulst A. Van, Thierry B., Chaix B., 2014. Assessing patterns of spatial behavior in health studies: Their socio-demographic determinants and associations with transportation modes (the RECORD Cohort Study). Social Science and Medicine 119: 64-73. DOI: 10.1016/j.socscimed.2014.07.026.

Pietrzyk-Kaszyńska A., Czepkiewicz M., Kronenberg J., 2017. Eliciting non-monetary values of formal and informal urban green spaces using public participation GIS. Landscape and Urban Planning 160: 85-95. DOI: 10.1016/j. landurbplan.2016.12.012.

Pocewicz A., Nielsen-Pincus M., 2013. Preferences of Wyoming residents for siting of energy and residential development. Applied Geography 43, 45-55. DOI: 10.1016/j. apgeog.2013.06.006.
Rantanen H., Kahila M. (2009). The SoftGIS approach to local knowledge. Journal of Environmental Management 90(6): 1981-1990. DOI: 10.1016/j.jenvman.2007.08.025.

Rinner C., 2001. Argumentation maps: GIS-based discussion support for on-line planning. Environment and Planning B: Planning and Design 28(6): 847-863. DOI: 10.1068/b2748t.

Rinner C., Bird M., 2009. Evaluating community engagement through argumentation maps - a public participation GIS case study. Environment and Planning B: Planning and Design 36(4): 588-601. DOI: 10.1068/b34084.

Salonen M., Broberg A., Kyttä M., Toivonen T., 2014. Do suburban residents prefer the fastest or low-carbon travel modes? Combining public participation GIS and multimodal travel time analysis for daily mobility research. Applied Geography 53: 438-448. DOI: 10.1016/j.apgeog.2014.06.028.

Schlossberg M., Shuford E., 2005. Delineating "Public" and "Participation" in PPGIS. URISA Journal 16(2): 15-26.

Schmidt-Thomé K., Haybatollahi M., Kyttä M., Korpi J., 2013. The prospects for urban densification: a place-based study. Environmental Research Letters 8(2): 1-11. DOI: 10.1088/1748-9326/8/2/025020.

Schmidt-Thome K., Wallin S., Laatikainen T., Kangasoja J., Kyttä M., 2014. Exploring the use of PPGIS in self-organizing urban development: Case softGIS in Pacific Beach. The Journal of Community Informatics 10(3): 1-12. Online: ci-journal.net/index.php/ciej/article/view/1080/1111 (accessed 7 August 2018).

Sieber R., 2006. Public participation geographic information systems: A literature review and framework. Annals of American Association of Geographers 96(3): 491-507. DOI: $10.1111 / j .1467-8306.2006 .00702 . x$.

Slotterback C.S., 2011. Planners' perspectives on using technology in participatory processes. Environment and Planning B: Planning and Design 38(3): 468-485. DOI: 10.1068/ b36138.

Ståhle A., 2006. Sociotope mapping - exploring public open space and its multiple use values in urban and landscape planning practice. Nordic Journal of Architectural Research 19(4): 59-71.

Talen E., 2000. Bottom-up GIS: A new tool for individual and group expression in participatory planning. Journal of the American Planning Association 66(3): 279-294. DOI: 10.1080/01944360008976107.

de Vries S., Buijs A.E., Langers F., Farjon H., van Hinsberg A., Sijtsma F.J., 2013. Measuring the attractiveness of Dutch landscapes: Identifying national hotspots of highly valued places using Google Maps. Applied Geography, 45: 220-229. DOI: 10.1016/j.apgeog.2013.09.017. 